ДВНЗ “Тернопільський державний медичний університет імені I. Я. Горбачевського МОЗ України”

\title{
ФОРМУВАННЯ ПОЗИТИВНОЇ МОТИВАЦІЇ ДО ВИВЧЕННЯ АНГЛІЙСЬКОЇ МОВИ (ЗА ПРОФЕСІЙНИМ СПРЯМУВАННЯМ) У СТУДЕНТІВ МЕДИЧНИХ ВНЗ ЗА ДОПОМОГОЮ ІНТЕРАКТИВНИХ ТЕХНОЛОГІЙ І МЕТОДІВ НАВЧАННЯ
}

\author{
I. Horbachevsky Ternopil State Medical University \\ BUILDING UP POSITIVE MEDICAL STUDENTS’ MOTIVATION TO \\ LEARNING PROFESSIONAL ENGLISH BY MEANS OF INTERACTIVE \\ TEACHING TECHNOLOGIES AND METHODS
}

\begin{abstract}
Мета роботи - з'ясувати особливості формування позитивної мотивації до вивчення англійської мови (за професійним спрямуванням) у студентів медичних ВНЗ за допомогою інтерактивних технологій і методів навчання.

Основна частина. У статті обгрунтовано ефективність застосування інтерактивних технологій і методів навчання у поєднанні з традиційними в процесі формування позитивної мотивації до вивчення англійської мови (за професійним спрямуванням) у студентів медичних ВНЗ. 3'ясовано рівень сформованості позитивної мотивації до вивчення англійської мови (за професійним спрямуванням) у студентів-медиків за допомогою інтерактивних технологій і методів навчання.

Висновок. Вміле використання інтерактивних методів і технологій у поєднанні з традиційними сприяє формуванню позитивної мотивації до вивчення англійської мови (за професійним спрямуванням) студентами медичних ВНЗ, їхній якісній фаховій іншомовній підготовці, розвиває професійні уміння на навички, активізує творчий потенціал, підвищує зацікавленість навчальною дисципліною.
\end{abstract}

Ключові слова: мотивація; інтерактивні технології і методи навчання; англійська мова (за професійним спрямуванням); студенти-медики; анкетування.

The aim of the work - to find out the peculiarities of building up positive medical students' motivation to learning professional English by means of interactive teaching technologies and methods.

The main body. The article presents the effectiveness of interactive teaching technologies and methods, which are used in combination with traditional ones in the process of building up positive medical students' motivation to learning professional English. A level of building up positive medical students' motivation to learning professional English by means of interactive teaching technologies and methods was determined.

Conclusion. Skillful use of interactive teaching technologies and methods in combination with the traditional ones contributes to building up positive medical students' motivation to learning professional English and the quality of their professional foreign language training. It develops medical students' professional skills, activates their creative potential and arises their interest to the subject.

Key words: motivation; interactive teaching technologies and methods; professional English; medical students; questionnaire.

Вступ. Проблематика підвищення конкурентоспроможності європейської системи вищої медичної освіти зумовила порушення ряду питань із формування позитивної мотивації до вивчення англійської мови (за професійним спрямуванням) у вищих медичних навчальних закладах України із метою забезпечення більш ефективної міжнародної співпраці та спілкування. У цьому аспекті необхідною умовою забезпечення успішної професій- ної діяльності майбутнього медичного працівника $€$ його якісна фахова іншомовна підготовка, яка сприяє швидкій адаптації в умовах іншомовного середовища.

Мета роботи - 3' ясувати особливості формування позитивної мотивації до вивчення англійської мови (за професійним спрямуванням) у студентів медичних ВНЗ за допомогою інтерактивних технологій і методів навчання.

\footnotetext{
() О. Д. Колодницька
} 
Основна частина. Невід’ємною складовою професійної підготовки майбутнього фахівця у медичних ВНЗ $є$ англійська мова (за професійним спрямуванням), метою якої є застосування отриманих теоретичних знань у практичних ситуаціях, наближених до реального професійного життя.

Джерелом забезпечення позитивної мотивації до вивчення англійської мови (за професійним спрямуванням) у студентів медичних ВНЗ є формування особистісних потреб у якісній фаховій іншомовній підготовці, які спонукають до постійної роботи над собою (lifelong study), шляхом застосування особистісно-орієнтованого підходу (студенти у ролі суб'єкта пізнавальної діяльності) та інтерактивного навчання, яке “найкраще сприяє співробітництву, порозумінню і доброзичливості, надає можливості дійсно реалізувати особистісно-орієнтоване навчання” [3], та розширює пізнавальні можливості студентів “зокрема у здобуванні, аналізі та застосуванні інформації з різних джерел” [3], створює колективні та особисті ситуації успіху (“Твій успіх іде на користь мені, а мій - на користь тобі” [3]). Інтерактивне навчання - це “співнавчання, взаємонавчання (колективне, групове, навчання у співпраці)”, де всі учасники є “рівноправними, рівнозначними суб’ єктами навчання” [3]. “Педагог виступає як організатор процесу інтерактивного навчання, консультант, фасилікатор дискусії” [3], зауваження якого мають конструктивний характер, тоді як студенти навчаються приймати виважені, “важливі рішення щодо процесу навчання, мають можливість спілкування і розвитку комунікативних умінь та навичок” [3], поєднуючи різноманітні види діяльності.

Формування позитивної мотивації до вивчення англійської мови (за професійним спрямуванням) у студентів медичних ВНЗ визначається низкою специфічних чинників: освітньою системою, освітнім закладом, організацією навчального процесу, системою взаємовідносин “викладач - студент”, їхніми суб' єктивними особливостями, специфікою предмета, виду діяльності (продуктивний, творчий або репродуктивний), зацікавленістю змістом і процесом навчання тощо. Невід’ємною умовою зацікавленості студентів навчальною діяльністю $\epsilon$ стимулювання їхньої пізнавальної активності, а також можливість проявити під час навчання розумову самостійність (вміння самостійно вчитися) та ініціативність. Основний засіб виховання стійкого інтересу до навчання - використання таких завдань, вирішення яких вимагає від студентів активної по- шукової діяльності. Навчальний матеріал і методи навчання повинні бути достатньо (але не надмірно) різноманітні [1].

О. Пометун виокремлює чотири групи інтерактивних технологій:

- інтерактивна технологія кооперативного навчання (робота в парах, ротаційні трійки, два - чотири - всі разом, карусель, робота в малих групах, акваріум);

- інтерактивна технологія колективно-групового навчання (обговорення проблеми у загальному колі, мікрофон, незакінчені речення, мозковий штурм, навчаючись - учусь, ажурна пилка, аналіз ситуації (case-метод), вирішення проблем, дерево рішень);

- технологія ситуативного моделювання (симуляції або імітаційні ігри, спрощене судове слухання, рольові ігри);

- технологія опрацювання дискусійних питань (метод ПРЕС, займи/зміни позицію, неперервна шкала думок, дискусія (в стилі телевізійного шоу, оцінювальна), дебати) [3].

Зазначені інтерактивні технології і методи доцільно використовувати у поєднанні з традиційними для організації аудиторної, позаудиторної та самостійної роботи студентів-медиків на практичних заняттях з англійської мови (за професійним спрямуванням). Завдяки вмілому використанню зазначених технологій і методів в умовах особистісно-орієнтованого навчання у студентів медичних ВНЗ формується позитивна мотивація до вивчення англійської мови (за професійним спрямуванням) та сприятливі умови для керованого викладачем і самокерованого, самостійного вивчення мови, а також з'являється можливість ширшого творчого самовираження усіх учасників навчального процесу.

Сучасна методика викладання англійської мови (за професійним спрямуванням) акцентує на комунікативній спрямованості занять, що сприяє практичному оволодінню мови через ситуації, наближені до реального професійного життя (йдеться про навчання студента-медика без примусу завдяки інтересу). Викладачу слід пам'ятати, що зовнішні, навіть найсприятливіші умови впливають на мотивацію навчання не безпосередньо, а тільки через внутрішнє ставлення до них самого студента. Тому необхідно передбачити систему заходів (ситуацій, завдань, вправ, спрямованих на формування здатності до навчання в широкому сенсі слова [2]. Формування професійної іншомовної компетенції здійснюється через підбір викладачем активного лексичного (найчастіше вживається в іншомовно- 
му професійному мовленні) і граматичного (сприяє вільному висловлюванню англійською мовою на будь-які теми зі спеціальності) мінімумів, відповідної системи комунікативних вправ і особистісно-орієнтованих інноваційних технологій у нерозривному поєднанні з традиційними.

Враховуючи вищесказане, можемо стверджувати, що до основних умов забезпечення формування позитивної мотивації до вивчення англійської мови (за професійним спрямуванням) у студентів медичних ВНЗ належать: психологічна атмосфера в групі; колективні, групові та індивідуальні форми організації різних видів діяльності; стимулююче середовище завдяки активній співпраці викладача і студента; безпосереднє залучення студентів до оцінки власної діяльності та формування у них адекватної самооцінки; новизна навчально-методичного комплексу з різноманітними завданнями на розвиток чотирьох видів мовленнєвої діяльності (читання, письмо, аудіювання, говоріння); цікавість і незвичайна форма викладу матеріалу, емоційність мови викладача; аналіз життєвих ситуацій; вміле поєднання викладачем традиційних та інтерактивних технологій і методів організації навчальної діяльності студентів-медиків; забезпечення в процесі навчання виникнення позитивних емоцій до навчальної діяльності, до її змісту, форм і методів здійснення.

Дієвими у процесі вивчення англійської мови (за професійним спрямуванням) вважають інтегративну та інструментальну мотивації. Інтегративний тип мотивації притаманний особистостям, які прагнуть вивчати мову для підвищення освітнього і культурного рівня. Інструментальний тип мотивації властивий особистостям, які вивчають мову 3 прагматичних міркувань, наприклад, з метою кар’єрного росту [4]. Позитивна мотивація (незалежно від типу) до вивчення англійської мови (за професійним спрямуванням) у студентів-медиків сприяє успішності та ефективності їхньої майбутньої професійної діяльності.

Рівень сформованості позитивної мотивації до вивчення англійської мови (за професійним спрямуванням) у студентів-медиків за допомогою інтерактив-

\section{Список літератури}

1. Зимняя И. А. Педагогическая психология / И. А. Зимняя. - Ростов-на-Дону : Феникс, 1997.

2. Маркова А. К. Формирование мотивации учения / А. К. Маркова. - М. : Просвещение, 1990.

3. Пометун О. I. Сучасний урок. Інтерактивні технології навчання : наук.-метод. посіб. / О. І. Пометун, них технологій і методів навчання було визначено шляхом проведеного анкетування. Кожному респонденту було наголошено на важливості незалежної думки. Анкета складалась із трьох запитань, а саме:

- яким використовуваним технологіям та методам навчання Ви надаєте перевагу на заняттях англійської мови (за професійним спрямуванням);

- які, на Вашу думку, інтерактивні технології та методи варто використовувати на заняттях англійської мови (за професійним спрямуванням);

- оцініть використання інтерактивних технологій і методів на заняттях англійської мови (за професійним спрямуванням).

Аналіз отриманих результатів свідчить, що на початковому етапі застосування інтерактивних технологій та методів навчання (другий семестр першого курсу (початок вивчення дисципліни)) переважна більшість респондентів (85,4 \%) віддавала перевагу пасивним традиційним методам роботи (читання, переклад і переказ текстів, а також виконання дотекстових та післятекстових вправ, які не вимагали творчості), тоді як на завершальному етапі вивчення англійської мови (за професійним спрямуванням) (другий семестр другого курсу (закінчення вивчення дисципліни)) - активним й інтерактивним технологіям і методам (робота в парах і малих групах, мікрофон, незакінчені речення, мозковий штурм, case-метод, дискусії, рольова гра) у поєднанні з традиційними (78,7 \%).

Висновок. Використання у підготовці студентівмедиків особистісно-орієнтованих інноваційних технологій у нерозривному поєднанні з традиційними сприяє розвитку інтересу, забезпечує формування позитивної мотивації до вивчення англійської мови (за професійним спрямуванням) студентами медичних ВНЗ і цілеспрямоване корегування професійної саморозвиваючої діяльності студентівмедиків викладачем із реальним прогнозованим результатом, створює передумови розвитку їхньої комунікативної компетенції, враховуючи індивідуальні особливості кожного як суб'єкта пізнання й діяльності, формуючи відповідальність за вирішення поставлених завдань, наближених до майбутньої практичної діяльності.

Л. В. Пироженко ; за ред. О. І. Пометун. - К. : Видавництво А.С.К., 2004. - 192 с.

4. Gardner R. C. Correlation, causation, motivation and second language acquisition / R. C. Gardner // Canadian Psychology. - 2000. - Vol. 41. - P. 1-24. 


\section{References}

1. Zimnyaya, I.A. (1997). Pedagogicheskaya psikhologiia [Pedagogical Psychology]. Rostov-na-Donu: Feniks [in Russian].

2. Markova, A.K. (1990). Formirovaniye motivatsii ucheniya [Building up motivation to Learning]. Moscow: Prosveshchenie [in Russian].
3. Pometun, O.I., \& Pyrozhenko, L.V. (2004). Suchasnyi urok. Interaktyvni tekhnolohii navchannia [Modern Lesson. Interactive teaching technologies]. Kyiv: A.S.K. [in Ukrainian].

4. Gardner, R.C. (2000). Correlation, causation, motivation and second language acquisition. Canadian Psychology, 41, 1-24.

Отримано 25.06.18

Електронна адреса для листування: kolodnytska_ol@tdmu.edu.ua 